\title{
The Nation State in the Global Economy
}

\author{
By Attiat F. Ott ${ }^{*} \&$ Nicole Bissessar ${ }^{ \pm}$
}

The paper revisits the use of Fiscal Policy as a viable instrument of public policy. Once dominated the landscape as a policy instrument in the nation state economy, it has all but abounded in the $21^{\text {st }}$ century. The paper shows a revival of fiscal policy to address issues in the global economy, in particular global spillover. Using data for two samples; developed and developing economies it highlights the spatial dimension of public functions in the global economy. (JEL $\mathrm{H} 3, \mathrm{H} 7)$

Keywords: State and Local Government; Fiscal Policies, Spillovers.

\section{Introduction}

"Public finances are being shaped by evolutionary dynamics such as Globalization”. Vitor Gaspar, 2016, p.166.

At the close of the $20^{\text {th }}$ century, there emerged a new global order where national boundaries of states no longer defined their economic policy. In a provocative paper: "Fiscal Policy for the Twenty-First Century: Testing the Limits of the Tax State", Gaspar (2016) raises the following two questions: In a world full of risk, how can public finances be made safe, and secondly, how can fiscal policy contribute to mitigating those risks?

The state public sector through its instruments of policy; discretionary fiscal actions, and the "automatic" stabilizers, seeks to mitigate the risk to the national economy from fluctuations of aggregate demand nationally, and, from spillovers from the international economy.

To focus on the role of stabilization policy active and passive that is pursued by the nation state, in the milieu of the international economy, the place to begin is with a framework that links globalization to the fiscal policy of the nation state. This paper is organized as follows: In the first section, a brief presentation about the functions of the nation state in a global context is presented. Next, a discussion of the spillovers - from the global economy to the national economy is presented. The response of the nation state to international spillovers is given in the following section. The last section concludes.

\footnotetext{
*Emeritus Professor of Economics, Clark University, Worcester, MA, USA \& President of the Institute for Economic Policy Studies, Worcester, MA, USA.

${ }^{ \pm}$Nicole Bissessar, Faculty of Economics, College of Online and Continuing Education, Southern New Hampshire University, USA \& Research Associate, The Institute for Economic Policy Studies, USA.
} 


\section{The Nation State Functions in a Global Context}

The fiscal functions of the nation state are commonly enumerated as falling into three categories: provision of public goods, achieving a modicum of equitable distribution of income and the stability of the national economy. In a global context, these functions take on a much broader role in that, risk to the national economy may be associated with "outside" risk arising from natural disasters and/or environmental hazards.

The close of the $20^{\text {th }}$ century ushered in a new global order. National economies are more open and the boundaries of the nation state no longer define its economic policies. In the global economy, governments face the same questions as the ones they face in their nation state - how to better the lives of their citizens. However, in such a milieu the sphere of influence of the nation state extends beyond its national border; it needs to address the question of how to prevent encroachment on its sovereign power by other nations, whether to opt for isolation or for economic integration.

Before addressing the functions of the nation state in the global economy, the place to start is a definition of the term "global economy".

Several articles provide such a definition. Robert Cox (1994) defines it as a "system generated by globalizing production and finance". Given that in the nation state, the functions of the state are enumerated as the provision of public and semipublic goods, redistribution of national resources to affect a modicum of distributive justice, and, the stability of the macroeconomy, the question that may arise then is: had globalization altered the functions of the nation state?

Putting aside for the time-being the distribution function of the public economy, the two functions that are most relevant in the context of the global economy are: the establishment and enforcement of individuals' property rights, and, shouldering the hazards of uninsured risk arising from the interactions of nations in the global economy.

Although the role commonly ascribed to the nation state does not differ much across states, in a global context such a role most likely will encompass broader issues than those pertaining to the national economy. Conflicts between states do arise because of externalities that cut across national boundaries such as pollutions, communicable disease and factor movements. Most contentious issues, which are not of the nation state own making are those associated with risk to life and property associated with wars, pollution and other health hazards. These types of externalities expand the nation-state's fiscal role not only for the purpose of addressing those originating outside of its border, but also spillovers arising from its own activities.

To lend the discussion an empirical focus, an organizational structure of the public sector's functions in the global economy is given in Table 1. The table gives an illustration of what has become known as the spatial dimension of the public economy. This dimension encompasses what is referred to as the "global" public goods. But first, what exactly is the global public good?

Kaul et al. (1999) defined it by reference to the activities ascribed to the public economy. Hence, a global public good, in lieu of the general label public 
good, must possess a spatial attribute, in addition to the traditional characteristics of a local or national public good. Accordingly, a global public good in addition to non-divisibility in consumption has to possess a spatial content. This dimension is illustrated in the following table.

Table 1. Spatial Dimension of the Public Sector

\begin{tabular}{|l|c|}
\hline Dimension & Public Sector Response \\
\hline $\begin{array}{l}\text { Global-Regional Concerns: } \\
\text { Defense }\end{array}$ & Risk Reduction through Cost Sharing \\
\hline Pollution and other Environmental Hazards & $\begin{array}{c}\text { Common Policies such as use of Affluent } \\
\text { Charges }\end{array}$ \\
\hline Infectious Disease & $\begin{array}{c}\text { Provide Tax and Transfer Payments } \\
\text { Internally and Externally }\end{array}$ \\
\hline
\end{tabular}

As shown in Table 1, the functions of the state in the global economy, take on a dimension which has yet to be recognized as functions of nation states worldwide. For example, the international community, through the World Health Organization (WHO), tackles communicable diseases worldwide, but such a function has not openly been recognized as a nation state function, for which budget allocation would be made and included in the nation-state budgetary allocation.

\section{Intra-States Spillovers and the Public Sector Response}

Within the national economy, Intra-states spillovers although most often recognized in national budgets in the form of "grants" and or "transfer payments" to local governments, this recognition and the need for action to address international spillovers have been quite limited. As seen below, (Table 2) such spillovers as well as cost sharing to address them, have been only recognized and implemented in the case of national defense, where the US and its allies share the cost of protecting their constituency from aggression. In the case of the other "spatial" spillovers, such as environmental hazards, compensation for cleanup for damages incurred may not always be recognized or forthcoming on the part of the nation states.

Given that for the provision of a public good to take place, whether the good is characterized as national, local or global, the assignment for its finance must be resolved on the basis of the so called "revealed" preference for the public good. This assignment is "more or less" resolved at the nation state level. That is, whether its finance should fall on the national, state or local government. In the global economy, this preference is often unknown. One needs to go beyond the traditional analyses of "revealed preferences" of the local or the state population to the preferences of the "global public". Since a definition of what constitutes a "global public" may be "good specific", for example the spread of a disease, the assignment of finance may not be easy to resolve, i.e. the free rider problem most likely to arise.

In the global economy, the nation state's functions take on a much broader 
role in that, the risks to the national economy may be associated with "out-ofnation" risks. These risks arise from natural disasters and/or environmental hazard which not always are recognized during budget formulation and executions at the nation state level. Given these types of hazards, and their international dimension, how might a nation's fiscal policy should be structured to address them?

One way to address this issue is through the classification of the public economy goods or functions into those goods/functions with global or geographic dimension and those with local or national dimension. Such a classification would be helpful for the structure of finance. This issue has been addressed in Kaul et al. (1999) paper.

According to the authors, certain goods, such as those provided to the alliance by NATO, although would fall in the category of public goods, should be viewed as "club" goods, as their provisions, and hence, their consumption are limited to members. This follows from the definition of a club good (where the good has both a geographic dimension and exclusion applies), hence, both provision and finance of NATO's activities should fall on club members.

On the other hand, if the good provided is viewed as a "global" public good such as the services of the World Health Organization (WHO) where its consumption is not limited to one nation or a group of nations, the burden of finance must be shouldered by all nations.

To resolve the issue of finance in the world economy requires the setting of framework for allocating the cost. Using the criteria discussed above in identifying a good, it could then be stated that: if a good, by meeting the needs of the local population, was also seen to contribute to the welfare of the world population, then the good should be viewed as a global public good. Its finance must be shouldered by all nations jointly. This identification, although may sound simple, its use for allocating the cost may not be so simple. As Kaul et al. (1999) aptly put it: "Who should be the beneficiaries - the publican-of the public good" (Kaul et al. 1999: 12).

One may be inclined to state further that both recognition of the beneficiary (or beneficiaries) and the allocation procedure devised in the case of both "public" and "merit" goods may be easier said than done. This is particularly so where a good's benefits spills over outside the country of origin. Even with such recognition it may not be possible to devise an acceptable cost sharing arrangement among the beneficiaries.

The complexities non-withstanding, surrounding not only the definition, but also, the distribution of the cost of provision of the global public good, discussed above, it may nonetheless be possible to link features of the global public good and the cost sharing arrangements.

Starting with the fundamentals that characterize a global public good: nonexcludable and, non-rival benefits, not-confined to a space, then the cost sharing arrangement for its provision could be related to one of two criteria (perhaps both): the level of GDP and the "globalization" feature of the economy. An illustration of what such an arrangement may entail is provided in Table 2. 
Table 2. Globalization and Response of The Public Economy

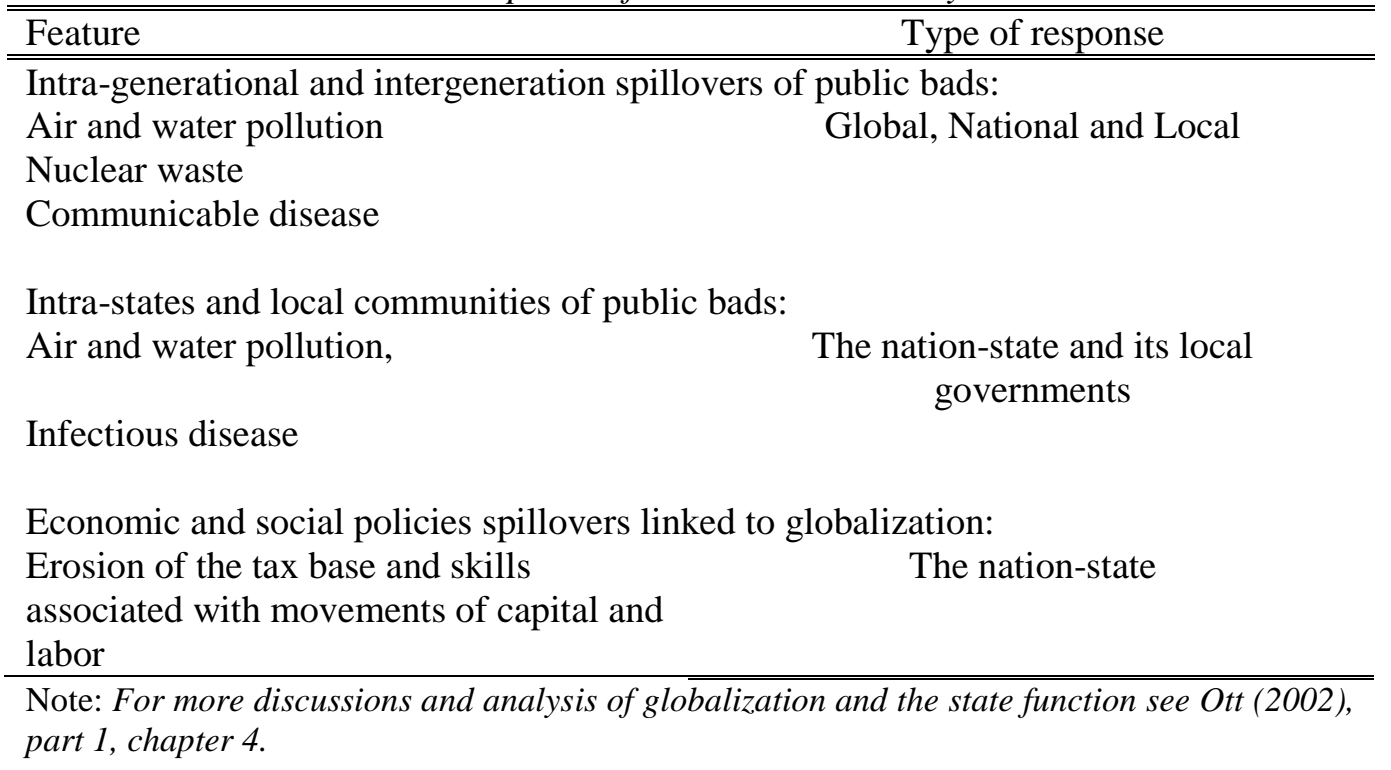

As Table 2, indicates, globalization expands the scope of the nation state public sector's sphere of influence, from addressing local and national needs, to effect a change in its role beyond its border.

Although in many respect, globalization expands the functions of the nation state, it imposes on it the additional task of monitoring spillovers and insuring that resources from home and/or abroad are there to deal with them.

Not all spillovers however, require coordination between nation states to deal with them. As seen from the table, the nation state has to address the majority of spillovers, as such spillovers occur nationally. On the other hand, when spillovers require a coordinating efforts and finance, such as the provision for defense, and, addressing the spillovers associated with the spread of communicable diseases, a mediating structure such as NATO maybe needed for this task.

Clearly, the expanding role of the nation state associated with globalization, in many respect imposes further burden on it, not only to expand its tax capacity, but also engaging other nation states in the process of reaching equitable distribution of the cost incurred in addressing global spillovers.

\section{Spatial Dimension of the Public Sector Functions}

As shown above (Table 2), public sector functions were cataloged along with their spatial dimension. The data presented in the Tables 1 and 2 makes it possible to differentiate between public sector's activities that have global, national, or local constituencies, as well as, makes it possible to assign responsibility for provision. Such an undertaking, however, requires detailed information about budgets, and the magnitude of the spatial spillovers. In the next two tables, Table 3 and Table 4, aim at capturing the spatial dimension of public sector spending for both the industrialized countries and the developing countries. The data in the tables, classifies public sector expenditures to correspond as closely as possible to the 
spatial dimension of the public sector functions.

The data reported in both tables for the year 2014, updates some of the findings that are reported in an earlier study (Ott 2002), for the purpose of identifying those expenditures that correspond to the classification presented above in Table 2.

Table 3. Spatial Dimension of Public Sector Functions: Advanced Economies (N=11) (2014, as Percent of Total Expenditures)

\begin{tabular}{|c|c|c|c|}
\hline Country & Global Concern & National Concern & Local Concern \\
\hline Austria & 2.00 & 70.90 & 27.10 \\
\hline Germany & 3.60 & 67.70 & 28.70 \\
\hline Italy & 4.30 & 71.00 & 24.60 \\
\hline Spain & 3.80 & 69.60 & 26.50 \\
\hline Czech Republic & 5.30 & 64.10 & 30.40 \\
\hline Iceland & 1.40 & 56.80 & 41.60 \\
\hline Israel & 16.10 & 51.10 & 32.80 \\
\hline New Zealand & 3.30 & 56.20 & 40.40 \\
\hline Singapore & 21.80 & 36.50 & 41.80 \\
\hline Sweden & 3.10 & 67.00 & 29.90 \\
\hline United States & 9.30 & 49.30 & 41.50 \\
\hline Mean & 6.73 & 60.02 & 33.21 \\
\hline Std. dev. & 6.51 & 11.08 & 6.79 \\
\hline \multicolumn{4}{|c|}{$\begin{array}{l}\text { Categories: } \\
\text { Global concern: } \\
\text { N; Defense and environmental protection } \\
\text { National concern: } \\
\sum ; \text { General Public Savings, public order and economic affairs and social protection } \\
\text { Local concern: } \\
\sum ; \text { Education, Housing and community development, Health and Recreation. }\end{array}$} \\
\hline
\end{tabular}

Source: International Monetary Fund: Government Finance Statistics Yearbook, 2015.

As shown in Table 3, the mean expenditures for the advanced economies for the spending category corresponding to the global concern, accounted for merely $6.7 \%$ of total budget expenditures in the year 2014. As would be expected, the spending category labeled spending to address national concerns absorbed the bulk of total budget funds with a mean value of $60 \%$. The last category, spending for meeting local concerns, had a mean value of $33 \%$ of total outlays. 
Table 4. Spatial Dimension of Public Sector Functions: Emerging and Developing Economies (N=30) (2014, as Percent of Total Expenditures)

\begin{tabular}{|c|c|c|c|}
\hline Country & Global Concern & National Concern & Local Concern \\
\hline \multicolumn{4}{|l|}{ Asia (9) } \\
\hline Bhutan & 0.3 & 59.4 & 40.4 \\
\hline \multicolumn{4}{|l|}{ China, P.R.: Macao } \\
\hline Indonesia & 5.6 & 65.2 & 29.2 \\
\hline Kiribati & 2.1 & 69.5 & 28.5 \\
\hline \multicolumn{4}{|l|}{ Marshall Islands, } \\
\hline *Nepal & 8.5 & 61.4 & 30.1 \\
\hline Philippines & 5.8 & 68.1 & 26.1 \\
\hline Samoa & 3.1 & 56.7 & 40.2 \\
\hline Solomon Island & 0.6 & 55.0 & 44.3 \\
\hline \multicolumn{4}{|c|}{ Central and Eastern Europe (8) } \\
\hline Albania & 3.0 & 67.9 & 29.2 \\
\hline Turkey & 5.3 & 64.6 & 30.0 \\
\hline Azerbaijan & 7.3 & 78.1 & 14.5 \\
\hline Belarus & 2.7 & 60.1 & 37.2 \\
\hline Georgia & 9.3 & 63.8 & 26.9 \\
\hline Kazakhstan & 5.8 & 55.1 & 39.1 \\
\hline Moldova & 2.2 & 60.9 & 36.9 \\
\hline Russian Federation & 4.3 & 69.2 & 26.6 \\
\hline \multicolumn{4}{|c|}{ Middle East and North Africa (6) } \\
\hline Egypt & 5.3 & 68.7 & 26.0 \\
\hline Jordan & 12.0 & 59.6 & 28.5 \\
\hline Lebanon & 8.7 & 81.1 & 10.3 \\
\hline Pakistan & 11.9 & 85.1 & 3.0 \\
\hline \multicolumn{4}{|l|}{ United Arab } \\
\hline \multicolumn{4}{|l|}{ West Bank and } \\
\hline \multicolumn{4}{|l|}{ WAEMU (5) } \\
\hline Angola & 12 & 65.8 & 22.1 \\
\hline Mauritius & 2.1 & 65 & 32.9 \\
\hline Seychelles & 9.4 & 57.9 & 32.6 \\
\hline South Africa & 3 & 67.4 & 29.5 \\
\hline Uganda & 11.6 & 63.6 & 24.8 \\
\hline Western Hemisphere & & Data for 2014 not ava & \\
\hline Mean & 5.48 & 65.33 & 29.25 \\
\hline Std. Dev. & 3.71 & 8.23 & 9.83 \\
\hline $\begin{array}{l}\text { *Data for } 2015 \\
\text { Categories: } \\
\text { Global concern: } \\
\sum ; \text { Defense and envir } \\
\text { National concern: } \\
\sum ; \text { General Public Sa } \\
\text { Local concern: } \\
\sum ; \text { Education, Housin }\end{array}$ & $\begin{array}{l}\text { nental protection } \\
\text { gs, public order an } \\
\text { nd community dev }\end{array}$ & $\begin{array}{l}\text { conomic affairs and so } \\
\text { pment, Health and Re }\end{array}$ & rotection \\
\hline
\end{tabular}

Source: International Monetary Fund: Government Finance Statistics Yearbook, 2015. 
Of note is the distribution of public spending, reported in the table, for two countries: Singapore and Israel. In the case of Singapore, the state's spending for meeting global concerns was equal to $22 \%$ of total budget spending with the category of spending with the highest percentage $42 \%$ went for meeting local and not national concerns. A somewhat similar distributional pattern was found for Israel where $16 \%$ of the total went for meeting global concerns; and almost one half of budget spending was allocated to address local concerns. Another interesting finding is the allocation of budget outlays in Sweden. The percentage distribution reported in Table 3, shows that only $3 \%$ of the total was devoted to the category of spending labeled meeting "Global Concerns". Since the allocation of budget spending reflects not only needs specific functions, but also, the country's defense posture and its global involvement it is to be noted when comparisons across countries regarding the distribution of public funds are made.

Looking at the corresponding data for the emerging-developing economies reported in Table 4, one discerns a different pattern among the different segment of this population. For the first group, Asia $(\mathrm{N}=9)$, whereas spending for meeting global concerns was a bit high for Nepal (8.5\%), Philippine (5.8\%), and Indonesia $(5.6 \%)$, Bhutan the Solomon Island devoted less than $1 \%$ of their total spending on this category.

The next group of countries comprise countries in Central and Eastern Europe $(\mathrm{N}=8)$, exhibits a spending allocative pattern similar to that observed for the developed economies (see Table 3). As to the distribution of spending for the Middle East and African countries $(\mathrm{N}=11)$, differ across the spectrum of this group of countries. For example, Jordon, Angola, Uganda and Pakistan have devoted in 2014 , over $10 \%$ of their state budgets on the category labeled; spending to meet "global concern" most of which undoubtedly went for national defense, perhaps to be expected given the nature of conflicts in these parts of the world.

With respect to the breakdown of spending between national concern and local concern, one observes similar pattern where the category of spending labeled national concern, absorbed $85 \%$ in Pakistan, $81 \%$ in Lebanon and $79 \%$ in the United Arab Emirate. This being said, one does not discern a pattern to the allocation, except that spending for meeting national concern is consistently the dominant feature in the spatial dimension of the State's functions.

It is worth noting that whenever comparisons are made, across samples at different levels of economic development, as well as form of governments; central versus federal, is that the findings are bound to reflect as much the form of government, hence the assignment of responsibilities, as public preferences for one or another type of public spending allocation. For example, a decentralized form of government is likely to have a higher level of spending on local concern than a centralized form of government. Likewise, a nation state that falls in a "war zone", or, faces the prospect of war with its neighbors, is more likely to allocate a higher percentage of its budget to meet "global" concern than other states that do not face the same prospects.

Given the divergence of needs across the samples as well as within each sample, the data reported in the tables, nonetheless paints a clear profile of a nation 
state's public sector activities nationally and in the global economy. What it does not convey however, is the implications of these activities for the fiscal policy of the nation state. How then might one infer, from these data the fiscal posture of an advanced nation or a nation in the process of development?

A closer look at the data reported in both tables, suggests that most of budget resources is devoted to address national and local concerns. Of the two categories of spending, spending for meeting national concern is likely to be altered up and down to affect the path of the economy. Spending for meeting local concern, in a decentralized setting may serve the same stabilizing function as spending for meeting national concern.

With respect to the category, spending for meeting global concern, although the bulk of funds in this category are spent on defense, some such funds are likely to have a stabilizing impact on the economy. As seen from Table 2 above, to the extent that a country may satisfy some of its demand through imports, adjustments in the level of spending on this category may have a fiscal impact not only on the importing country but on the economy of exporting countries as well.

For example, in the majority of the advanced economies, the largest component of spending that meets global concern is spending for defense. This category of spending is not designed to influence the path of the national economy. This is because, expenditures on defense, for the most part, meet needs not related to the fiscal posture of a nation. In other words, the determination of the level of spending on defense is in response to concerns not related to the fiscal posture of the nation at any given time. Accordingly, higher or, lower levels of spending on defense, although impacts the growth path of the economy, as well as, the stability of the world economy, its level and spatial dimension do not rise or fall in response to changes in aggregate demand at home or abroad.

The spending category of interest, as it impacts the fiscal stand of the nation state, is that category identified in Tables 3 and 4 as spending meeting "national" and "local" concerns. The level of spending on each one of these two types may be said to be a function, not only of needs, but also of the growth of the national economy. In periods of slack in private sector demand, the state may be able to adjust its level of spending on these categories, thus through the "multiplier" effect achieves a higher growth path for the economy. Similarly, in periods of high employment, the state can adjust its level of spending on these categories to prevent escalation of prices.

Having attributed to this category a stabilization role, one needs to inquire as to the spatial impact of the "up", or, "down" level of spending on this category. From the tables, the stabilization-function induced changes in the level of spending on functions identified in the category, i.e., transportation and communication will have a spatial effect which may impact the level of activities, hence spending globally.

Public sector spending meeting global concern, aside from defense, may play a role as a fiscal stabilizer both at home and abroad. For example, as reported in Table 2, to the extent that a country may satisfy some of its demand through imports, adjustments in the level of the state expenditures on this category may have a fiscal impact not only on the importing country, but on the economy of the 
exporting country (countries) as well, finances have to increase to meet the required expenditures to deal with them. On the revenue side of the state budget, it is unlikely that spillovers associated with state taxes occur, except in the case of corporate taxation of foreign direct investment (FDI). Such spillover has been recognized recently.

In an IMF paper, published in 2014 by Keen et al., identified another source of spillovers - the corporate tax effect spillovers where tax policy of one country spillover and impact the economies of other countries. The issue of concern here is the effect of international tax spillovers on the design of taxation and their stabilization effects on the developing economies.

Recognizing that, in the global economy, both spillovers of "public bad", such as pollution and the erosion of tax bases do occur, as well as "public good" does occur one needs to inquire as to the response of the public economy in the nation state to spatial spillovers. If it is assumed that spatial "public bad" do exceed "public good" spillovers, this would mean that both the nation- state taxes and expenditures would be impacted.

If the nation state, in response to the spatial spillovers, is induced to alter the design of its tax system, from direct to indirect taxation - from the corporation income tax to an excise tax, this shift would likely have a significant effect on the built-in stabilization of its tax system. On the other hand, if, global spillovers were in the nature of "public good", that impact positively the welfare of citizen, the nation state then may be induced to offer the initiators of said spillovers, tax benefits or free services.

Clearly then, documenting the impact of globalization on the public finances of the nation state, especially, spillovers is critical to understanding the kind of response that the nation-state ought to pursue (see Garrett 2000 and Quin 1997).

The public economy in the nation- state, in short, bears the responsibility of carrying out several tasks: the provision of public and semi-public goods, addressing spillovers, especially spillovers associated with the so called "public bad", as well as enacting policies that would enhance society's welfare.

Performing these functions, the state does so, within the constraints it faces locally and globally. With high and rapid degree of integration of the world economies, developments in one country or region do spillover on the rest of the world. Accordingly, to assess the impact of fiscal policy pursued by one country, one cannot but pursue knowledge about developments in the region where it is geographically located as well as developments that are taking place in the rest of the world.

Given that fiscal actions of a country or a group of countries in one region, most often are not independent of events taking place elsewhere, an analysis of the fiscal posture taken by one country, whether developed or developing should be viewed in the context of events and policy undertaken by other states in the world economy. In this regard, the analyses of the fiscal posture and fiscal policies pursued by the 88 countries reported in the IMF (2015) report, is valuable, not only for its empirical content, but in highlighting the need to view fiscal policy pursued by one country not in isolation but within the context of the global economy. 
Although the main focus of the IMF report was on providing an empirical test of the significance of the "built-in stabilizers for the stability of the economy, among other lines of inquiry the report pursued, is the discovery of those economic variables that are of significance for determining the effectiveness of fiscal policy. Of interest is the link, the study highlights, between low inflation, low growth and the public debt.

\section{Conclusion}

The public economy of the nation state bears the responsibility of carrying out several tasks: the provision of public, semi or club goods and addressing spillovers, national as well as global.

Performing these functions, the nation state does so, within the constraints it faces. With a rapid pace of integration of the world economies, developments in one country or region spill over on the rest of the world. Accordingly, to assess the impact of public sector actions in one nation on the economies of other nations, one cannot but pursues knowledge about developments and policies pursued globally.

Although the focus of the paper was limited to ascertain the effects of globalization on the behavior of one state in such a milieu, it was soon evident that such an assessment can only be pursued in a global context.

Given that fiscal action of a country or a group of countries in one region of the world most often are not independent of events or actions taken place elsewhere, an analyses of fiscal actions pursued by one state can only be assessed within a global framework of analyses.

This what this paper attempted to do by recognizing the fiscal actions of the nation state not in isolation but in the context of events and issues relevant to the functioning of the global economy. In this regard, the data and analyses of the fiscal posture of both developed and developing economies presented above (Tables 3 and 4) are valuable, not only for their empirical content, but also in highlighting the need to view fiscal policy decisions of one country not in isolation but within the context of the global economy.

\section{References}

Cox R (1994) Global restructuring. In R Stubbs, G Underhill (eds) Political Economy of the Changing Global Order, 45-59. New York, NY: ST. Martin Press.

Garrett G (2000) Capital Mobility, and exchange rate and fiscal policy in the global economy. Review of International Political Economy 7(1): 153-70.

Gaspar V (2016) Fiscal policy for the twenty-first century: testing the limits of the tax state? In O Blanchard, R Rajan, K Rogoff, LH Summers (eds) Progress and Confusion; The State of Macroeconomic Policy, 165-175. USA: The MIT Press.

IMF (2015) Fiscal Monitor, Now is the Time: Fiscal Policy for Sustainable Growth, April 2015. Available at: https://bit.ly/2HY364E.

Kaul I, Grunberg I, Stern M (1999) Global Public Goods: International Cooperation in 
the $21^{\text {st }}$ Century, 30-31. New York: UNDP/Oxford University Press.

Keen M, Perry V, de Mooij R, Matheson T, Schatan R, Mullins P, Crivelli E (2014) Spillovers in International Corporate Taxation. International Monetary Fund, Staff Paper. Available at: https://bit.ly/2wJhx6g.

Ott AF (2002) The Public Sector in the Global Economy: From The Driver's Seat to the Back Seat. Chelthenham, UK \& North Hampton, US: Edward Elgar Publishing.

Quinn D (1997) The Correlates of changes in International Financial Regulations. American Political Science Review 91(3): 531-57. 